A LITERATURA

GALEGA ANTERIOR AO

REXURDIMENTO

Anxo Tarrío Varela

Universidade de Santiago de Compostela 

Baixo este título anunciouse no programa a miña intervención nestas xornadas dedicadas a observar os textos escritos en galego durante o período que abrangue practicamente toda a primeira metade do século XIX. Concretamente, entre 1797 e 1846. A primeira das datas, 1797, correspóndese co ano no que Manuel Pardo de Andrade fixo uso do galego no xornal máis importante de España naquel momento, o Diario de Madrid, cun orixinal soneto entre erótico e humorístico que ben podemos ler aquí, pola rareza que supón, até certo punto, o uso do galego nun estrofismo culto nesa altura:

Mais Garrida que a [r] osa no seu leyto,

Cando pola mañan a rega ó ervallo

Mais vixiosa, que aquil que sube o atallo

Sin baixar os cadris, sem[pr]e direyto,

Istaba a dona do meu amante peyto.

Nó eydo di seu pay, no seu travallo:

Cheguey eu, sentouse ela, e doume un tallo

Que era come úa pera lindo e feyto:

Discubrinlle o meu mal, a pena mińa

Os choros meus, e todo o meu tormento,

E choraba di gozo a Garridiña:

Pedinlle a man brincando de content $[\mathrm{o}]$

${ }_{i} \mathrm{E}$ creeredes, que xia a bribona tińa

Feyto a outro papel di casamento[!]

O brusco cambio da descriptio puellae á exclamatio que lle segue supón un trazo de modernidade, en tanto en canto destrúe o tópico renacentista tan estendido e manoseado polos poetas maiores e pequenos, producindo un efecto humorístico que, este si, era moi practicado na altura por poetas como o cura 
de Fruíme ou Francisca de Isla ao denigrar dos seus inimigos ou dos críticos que ousasen descualificarlles un texto, ou por outras razóns que propiciaban o rexoubeo, rexistro para o que utilizaban exclusivamente a lingua galega, feito que non debemos desbotar pois quizais ten unha pertinencia que pode explicar moito acerca da serodia incorporación da galega ás literaturas peninsulares contemporáneas. O exemplo da décima de Cornide Saavedra contra Salgado é ben elocuente.

Anque puxeche o pucheiro

para cocer no Parnaso, foiche a carne do Pegaso e estaba duro o calleiro. A leña veu do palleiro púxocho chamuscado, mais porque mal amañado fose o teu presente asnal, botáchelle pouco sal e saíuche mal, Salgado. (1761)

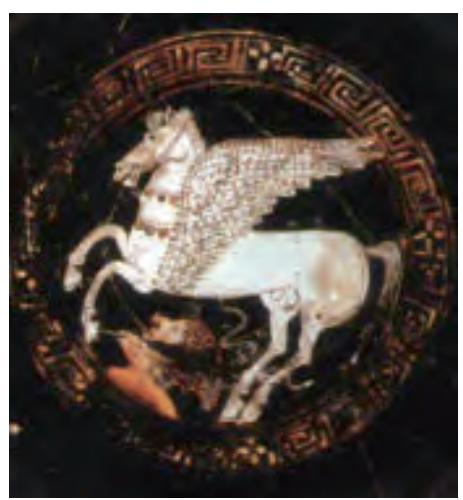

Representación do Pegaso mitolóxico

A segunda data, 1846, tén o carimbo emblemático de ser o ano en que tivo lugar o levantamento do comandante Solís en Lugo. Como é ben sabido, o 2 de abril de 1846 o segundo Batallón do Rexemento de Zamora, que estaba de paso para Valladolid, alzouse contra o goberno conservador de Narváez (partido moderado) para poñer no seu sitio a Francisco Javier Istúriz, do mesmo partido. Non foi secundado no resto de España, pero en Galicia tomou un nesgo galeguista que había servir para asentar os ideoloxemas da resistencia identitaria. A raiz dese levantamento, promulgouse unha "Proclama de la Junta del Gobierno de Galicia”, escrita por Antolín Faraldo (Betanzos, 1823 - Granada, 1853), na que, entre outras cousas dise que:

Galicia, arrastrando hasta aquí una existencia oprobiosa, convertida en una verdadera colonia de la Corte, va a levantarse de su humillación y abatimiento (a cursiva póńoa eu). 
Podemos dicir que aquí comeza a elaborarse o discurso galeguista contemporáneo na súa etapa provincialista. Pero xa o ano anterior, en 1845, o mesmo Antolín Faraldo e os seus amigos sacaran á luz un texto de intención manifestaria que titularon "Nuestra bandera literaria”, baixo o lema “¡Abajo las reglas, las escuelas i los maestros!", onde, ademais de dar carta de nacemento á literatura galega contemporánea, dise, entre outras cousas:

Hace tres años que anunciamos la emancipación absoluta como el gran progreso del genio i la más preciosa conquista de las letras. Desde entonces seguimos meditando sobre lo que talentos envilecidos acusaron de disolución i anarquía, i cada día nuestras ideas se robustecieron más i más (...) Establecemos por principio que todo escritor puede presentar al mundo sus concepciones bajo la forma más extraña que puedan ser engendradas por el entendimiento, hollando las convenciones literarias, opresoras de la razón i de la conciencia, que apagan la inspiración i marchitan las inteligencias más lozanas (...) La literatura gallega jamás puede alcanzar verdadera i legítima originalidad si no se emancipa de las escuelas i hace pedazos el cetro de los maestros, proclamando la independencia del escritor (a cursiva póńoa eu).

El Porvenir, Santiago de Compostela, 1845.

Entre as dúas datas, está o obxecto de estudo que centra a atención destas xornadas, deste Simposio, é dicir, un corpus de textos en prosa e en verso que reúne todo o que se coñece até o momento redactado en lingua galega naquel período, froito do paciente labor do equipo responsábel da edición do volume que leva por título Papés d'emprenta condenada. A escrita galega entre 1797 e 1846, publicado polo Consello da Cultura Galega en 2008 e coordinado por Rosa Aneiros, no que cómpre salientar o inxente traballo de fixación dos textos que levou a cabo o profesor Ramón Mariño, a quen agradezo a invitación para estar hoxe aquí.

Porén, quero facer algunhas consideración que coido necesarias para mellor entender o devandito período no que atinxe ao concepto de literatura galega. En primeiro lugar, convén dende agora deixar claro que estamos diante dun baleiro, é dicir, se por algo se define a literatura galega daquela altura, dende o punto de vista sociolóxico e sistémico, é pola súa inexistencia, por iso teremos que facer unha especie de fotografía en negativo, dende o momento en que un corpus textual non abonda para constituír por si só unha literatura, por poucos que sexan 
os requerimentos que lle queiramos esixir para consideralo tal. Hoxe en día, dende logo, temos isto bastante claro, dende o momento en que consideramos que unha literatura é un sistema, unha institución social que se inscribe noutros sistemas sociais, semióticos e culturais que son os que lle dan posibilidades de existencia e lexitimidade.

Efectivamente, cara a finais do século XVIII, é dicir, precisamente no periodo que estamos a observar, a emerxencia do concepto moderno de literatura deu lugar a unha serie de reflexións sobre o seu estatuto na sociedade. Precisamente en 1800, Germaine Necker, baronesa de Staël-Holstein (París, 1766-1817), máis coñecida polo nome de casada, Madame de Staël, publicou un texto titulado De la Littérature considerée dans ses rapports avec les institutions sociales, onde xa estabelece que un artista debe pertencer ao seu propio tempo. Doutra banda, o propio proceso de institucionalización da literatura está estreitamente relacionado co concepto de esfera pública teorizado modernamente por Jürgen Habermas (1981), dado que a evolución dende o réxime de mecenado (Lefevere [1992] 1997), xa en decadencia naquel momento, até a profesionalización do escritor, é inseparábel da consolidación dunha esfera pública por parte da sociedade civil. Unha esfera pública que, para o caso da literatura galega, de existir, existiría para acoller a produción literaria escrita en castelán e xa canonizada. É dicir para acoller o macrosistema literario español.

De todos os xeitos, aínda que, como se ve, o termo institución referido á literatura non é novo, o concepto de institución literaria tal como se usa na actualidade foi introducido por Harry Levin en 1946. No uso máis xeral, trátase dun ámbito social específico que contén entidades lexitimadoras (academias, salóns, ateneos, revistas, premios, bibliotecas, asociacións de escritores, docencia universitaria, crítica literaria, mecanismos de censura) e tamén normas e códigos. Entidades, normas e códigos das que carecía a produción textual en lingua galega naquela altura.

Doutra banda, o uso do concepto de institución por parte da Socioloxía da literatura tende a analizar esta como un discurso sometido ás leis sociais e, polo tanto, trata de localizar a literatura nunha zona propia que, non embargantes, estea definida polas leis xerais da sociedade. A esta concepción da literatura hai que engadir, como xa é ben sabido, o concepto de campo literario proposto por Pierre Bourdieu. Estas son hoxe cousas ben asimiladas. En efecto, ambos concep- 
tos, institución e campo literario consideran que a literatura está gobernada por dous tipos diferentes de normativas: por unha banda, insírese no que Bourdieu denomina 'campo do poder'; pola outra, obedece ás súas propias leis, que gozan dunha certa autonomía, de tal forma que a literatura pode ir, en aparencia, en contra da lóxica do mercado, posto que se percibe como allea a esta. En concreto, a oposición proposta polo sociólogo francés entre gran produción e produción restrinxida constitúe unha explicación das actitudes máis frecuentes nos eidos da creación e a crítica literarias. Habería aínda que desenvolver máis conceptos que hoxe manexa a teoría sociolóxica da literatura pero todos nos levarían á conclusión de que falar de literatura galega no periodo acotado para este simposio é a todas luces un abuso de expresión. Porque, ademais, se ben a importancia que se lle dá a estes feitos varía dunha aproximación teórica a outra, todas coinciden en que a institución literaria non é unha entidade estática, senón unha esfera en perpetua mudanza onde teñen lugar continuas loitas pola hexemonía, no sentido gramsciano do termo. Precisamente, este dinamismo constitúe un dos trazos máis definitorios da institución, en tanto reflexo da pertenza da literatura ao social. E nada disto atopamos en Galicia dende o punto de vista da produción textual en lingua galega da época que estamos a observar, agás as escasísimas excepcións que veremos.

Hai que pensar tamén noutro concepto emerxente dende hai algúns anos que convén bastante ao caso que hoxe nos ocupa. Falo do concepto de literacidade, ben estudado por Daniel Cassany (2006) no libro que titula Tras las líneas. Sobre la lectura contemporánea. En sentido estricto, por literacidade, palabra que é un calco da correspondente inglesa, literacy, enténdese a capacidade de desenvolvemento das competencias que pode demostrar unha persoa na lectura e na escritura. Asociada a esta definición atópase a dificultade de estabelecer o conxunto de habilidades e cońecementos que deberían integrar a literacidade, sobre todo cando este concepto pretende ser aplicado a contextos culturais de natureza diversa. A habilitación da idea de literacidade funcional procura precisamente englobar o conxunto de destrezas fundamentais para o desenvolvemento das actividades que se consideran necesarias e imprescindíbeis no interior dunha cultura, e excede as máis reducidas dimensións que amosaba a idea de alfabetización. A medición estatística dos niveis de literacidade dunha sociedade determinada adoita ser posta en relación co grao de desenvolvemento da mesma. Nin que dicir tén que isto, 
aplicado á Galicia da primeira parte do século XIX, onde batemos en primeiro termo cunha sociedade maiormente rural e empobrecida e cun índice de alfabetización próximo a cero, aínda nos asolaga máis na imposibilidade de falar para aquel tempo dunha literatura galega en termos de seriedade.

Doutra maneira podemos ver as cousas e de feito se ven, cando nos situamos na perspectiva da análise dos discursos xornalístico, histórico, filolóxico, sociolingüístico, etnográfico ou tamén da análise da literatura popular de transmisión oral, a cuxa realidade evidente pertencen moitos dos textos que nos ocupan, pois non hai dúbida de que a súa difusión tivo que facerse fundamentalmente por esa vía nos cronotopos apropiados, é dicir, nas reunións dominicais nos adros das igrexas, no reducto doméstico dos faladoiros arredor da lareira, nas feiras e mercados, entre outros lugares propicios ao encontro social e a relatar historias e contos. Polo tanto, insisto, as cousas poden verse doutro xeito moi diferente, e pleno de interese, neses campos que non é da miña competencia afrontar aquí. Moito me parece, pois, dada a pobreza textual con que nos atopamos neste período dende o punto de vista do dinamismo dos paradigmas formais, retóricos, etc., que definen unha institución literaria, que a un historiador e analista da literatura non lle queda máis saída que situarse nun observatorio inmanentista e textocentrista se quere tirar algún partido do seu esforzo analítico. E así situado, teño que facer unha pequena incursión no período que a historiografía literaria galega deu en denominar séculos escuros para ver que nos ofrecen de novidade os textos contidos no volume citado dos Papés d'emprenta condenada. Faremos un pequeno percurso cara atrás no tempo, a ver qué atopamos. Polo demais, son cousas xa ben difundidas (Tarrío Varela, 87-105).

Non iremos máis alá do século XVII. Dada a escaseza de textos dese século, non estará de máis reproducir aquí as únicas mostras de soneto barroco que se conservan e que son xa ben coñecidas, pois posúen unha factura literaria moi estimábel.

Sabido é que se salvaron da incuria e do tempo grazas a que estes sonetos foron impresos no volume homenaxe que se ordenou recompilar en honra da raína dona Margarida de Austria, con motivo das exequias celebradas na súa memoria, no ano 1611, a cargo da Real Audiencia do Reino de Galicia. O libro compúxoo en 1612, cun esmero exemplar, o impresor Juan Pacheco, de Santiago de Compostela, e foi o seu coordinador un dos dous poetas que colaboraron nel en lingua galega, Juán Gómez Tonel. O outro poeta chamouse Pedro Bázquez de Neyra. 


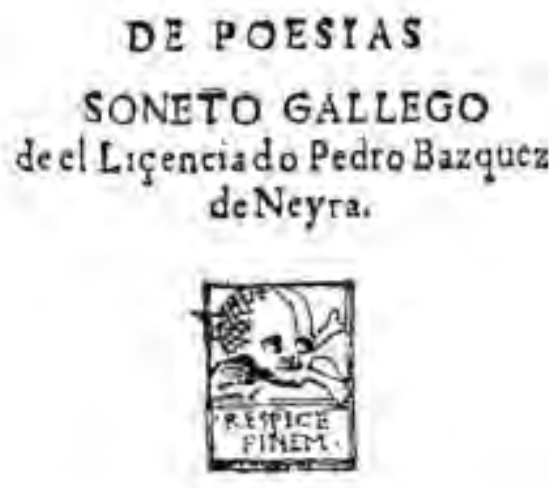

Morte ertuel efa tredora maria de roubar de non catoá humana rida conque ollos ápodeche ber comprida na fanta REINA que oge perde Efpañat

Se aquel rancor que te carcome e laria che cina í mao para matar ergida, non deras noutra parte efa ferida dondenó forsálaltima tamaìa?

Nonle torçars aquel fatal coflume yáley que yguala do morrer na forte, os altos Reis, co os baijos labradores?

Terrible en fin ę teu poder, ó Morte, poisdiante de ti Reis, élenores fon nebos, fombraspoo, fonbento sfume. 


\section{DISCVRSO TERCERO}

\section{SONETO CON FALDA}

deluan Contz Tonet.

Turbas corran as Agoas, poña lusa o. Ayredenfo,en merancora tanta queyrne o Fogoa Tersa, que Sin pranta negue a o fortuto ano keu trebuto;

Mentras a Porciado PhilippoBruta enoshombras da fama facrofancs Peyrgue áoCeo, que fúa groria eanta collendo en fror, ojámaduro fruto.

Perdeu martando tan ditola vida a Humildá preço, a Piadade tempro, (que derruboúo o Morte tua Gadalia)

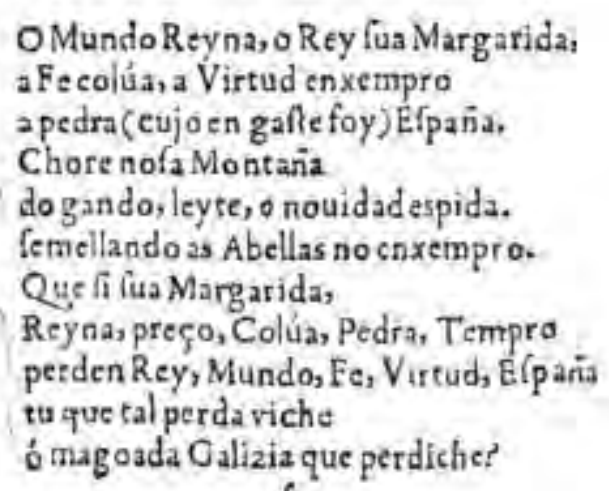

Á parte de ponderar no que vale a boa factura elexíaca dos sonetos de cadanseu autor, que se axustan á estética propia do Barroco e á retórica do xénero con apostrofismo patético e rancoroso contra a Morte igualadora, que non discriminou nin respetou sequera a excelencia da raíña Margarida, interesa rexistrar o sentimento de marxinación que se desprende do último verso de Gómez Tonel ("magoada Galizia”) e a contraposición entre este país e o resto de España, ao lle preguntar a aquel se realmente tén conciencia do que perdeu coa morte de dona Margarida: "tu que tal perda viche / ó magoada Galizia que perdiche?”. Agroma 
aquí xa un discurso que nos fala do malestar afogado con que certos próceres galegos vían o estado de prostración de Galicia.

Tamén do século XVII datan unhas décimas moi graciosas e elaboradas con man segura, nas que Martín Torrado, que fora reitor do colexio Fonseca e párroco dunha pequena aldea galega, sae ao paso da famosa polémica que xurdiu no ano 1617, mesmo coa participación do gran Francisco de Quevedo e Villegas, acerca da pretensión de nomear Teresa de Ávila copatroa de España, xunto a Santiago Apóstolo. O desenfado e a ironía con que están escritas, así como o bo oficio que mostra o crego, autorízannos a pensar que con seguridade se perderían outras composicións da súa man. Unha revisión desta composición, por rápida e pequena que sexa, indícanos que estamos diante dun estrofismo culto de non doada fábrica cando as décimas están ben elaboradas, como é o caso.

Santo da barba dourada, vello honrado, meu patrón, raio, fillo do trebón, capitán de roxa espada, señor da cruz colorada, valente e forte guerreiro quen todo o mundo enteiro polo mar e pola terra, chama, na paz e na guerra, Sant-Iago o cabaleiro.

Eu, meu santo, oín agora ao crego desta maneira: que vos dan por compañeira unha santa, gran doutora. ¡Vállame Nosa Señora! Ende, ¿`ós non bastás sóo para desfacer en póo cantos mouros e xudeus houber contra a fe de Deus? Decíao el meu abóo 
¿Elo é que non podés?

Eu non sei como isto sexa,

ou debe ser de envexa

do ben que a España facés.

Eu non vin tal entremés:

que a un crego lle fagan ter

unha freira por muller.

¡Arreda, vai Satanás!

Santo, vós, se casás,

dais ao mundo en que entender.

Ora, pese a tal, comigo,

non vos deran por compadre

a San Lourenzo, ou ao padre

San Vincenzo, ou San Domingo;

en tal preito non delingo.

E a nosa Santa Tereixa,

¿Non ha te-la mesma queixa,

pois vola dan por muller

sen preguntar se ela quer,

se ela toma ou se ela deixa?

Tamén sabemos que a Universidade compostelá convocaba cada ano, a partir de 1536 e en honra da memoria de Don Alonso de Fonseca O Grande, as chamadas Fiestas Minervales, ás que acudían poetas de terras varias na procura de premios e agasallos. Anque a convocatoria se facía pensando soamente no concurso da lingua castelá ou da latina, de xeito esporádico deuse acollida nela á lingua vernácula. Da meirande parte destas festas non se garda cousa ningunha que non sexa a noticia de se teren celebrado. Unicamente se imprimiron, e por iso se zafaron do esquecemento, as composicións que concorreron ás devanditas festas no ano 1697 e tamén as resultantes dos concursos convocados para celebrar a canonización de Pío V no ano 1713. 


\section{FIESTAS MINERVALES, Y aclamacion perpetua de las Mulas, à la inmortal memoria de el lluf. trifsimo, y Excelentifsi- mo Señor \\ D. ALONSO DE FONSECA El Crande,}

ARZOBISPO DE TOLEDO, Y DE SANTIAGO, $P O R$

SV ESCVELA, Y VNIVERSIDAD,

Q $V E$

AFECTVOSAMENTE LAS CONSAGRA, DEDI:

ca, y ofrece, al Excelennfisimo Seńor Conde de

Monte-Rey, fo Protector, Vaiedor,

y Mecenasa

POR MANO DEEL DOCTOR D. TOSEPH VARE-

lay Va/adre, Retor de dirba Viawerfidad, y Priar de la Sanicge

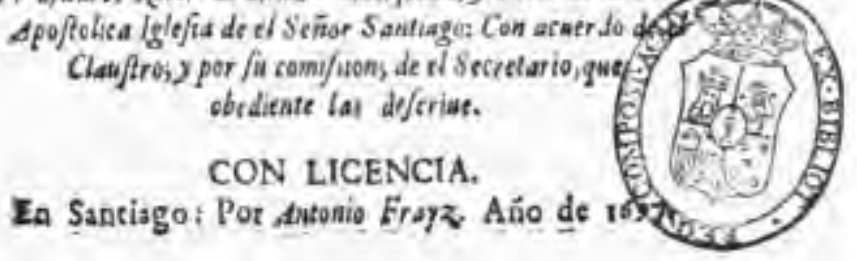

Desas festas de 1697 quedou unha serie de nove romances en cuartetas octosilábicas que máis nos interesan dende o punto de vista lexicográfico ca outra cousa, dada a súa escasa ambición estética (moi semellante á pouca que atopamos no corpus que nos ocupa hoxe da $1^{\text {a }}$ metade do XIX), anque non estean exentos de graza e desenfado. Hai que ter en conta, por outra parte, que estas composicións elaborábanse baixo tema obrigado, que era anunciado na convocatoria, polo que a libre inspiración, preocupacións e inquedanzas do poeta víanse así moi recortadas en favor do enxeño, sempre plausíbel pero que é cousa ben 
diferente. En concreto, o lema do segundo dos sete temas en loanza de Fonseca propostos para as Minervais de 1697 rezaba así:

Si Santiago vive más obligado al Señor Don Alonso de Fonseca, que el Señor Don Alonso vivió a su patria, resuelto en veinte copias de romance gallego, y en favor de nuestro fundador. Y será el primer premio una medalla de oro con la efigie del Santo Apóstol. El segundo tres tenedores y tres cucharas de plata. El tercero ocho libras de chocolate (a cursiva póñoa eu).

De entre os romances conservados, hai un no que nos interesa parar a atención, pois, deixando a un lado o que de valioso poida ter literariamente, infórmanos dun sentimento que seguramente estaría algo estendido en certos medios: o da marxinación da lingua galega e, por extensión, de todo o galego:

$$
\begin{aligned}
& \text { Xa que nos puxo o certame } \\
& \text { a porfía ou o problema } \\
& \text { na nosa lingua esquencida } \\
& \text { nomais que por ser galega } \\
& \text { ledo agora hasta nomais } \\
& \text { porque lle coupese a ela } \\
& \text { no ceu daquel gran escudo } \\
& \text { tan siquer o ter estrela } \\
& \text {... }
\end{aligned}
$$

É un sentimento que convén rexistrar porque nos informa de que debeu existir sempre algún descontento ao longo destes séculos que pode explicar as protestas, por exemplo, que pouco máis adiante había emitir o Padre Sarmiento e que mantivo viva a semente que daría froitos ben vizosos, definitivamente, no Rexurdimento do século XIX.

Pola súa parte, o propio Padre Sarmiento, que se ergueu airadamente contra da, xa de por si escasísima, escolarización do neno galego en lingua castelá e aínda aconsellou a predicación e a confesión na lingua do país, como é ben sabido, escribiu abundante e intelixentemente sobre a lingua galega e levou a cabo traballos de campo que aínda hoxe poden considerarse de grande utilidade e fino espírito observador. Precisamente, con parte do material recolleito propoñíase elaborar, 
baixo o pseudónimo de "O poeta Marcos da Portela", unha longa sarta de coplas que, como resumo dun título moito máis longo, coñécense por Diálogo de 24 rústicos, pero das que só compuxo (iso si, con graza e ritmo populares) 1.201, correspondentes a media ducia de personaxes.

No chan que en Morrazo
chaman os galegos
chan de Parafita,
que chega hasta o ceo,

que está no camiño

que vai ao Ribeiro

dendes Pontevedra,

a vila do reino;

a umha legoína,

camińo dereito

-fai conta que sigues

o rumbo surlesto-

se sube en relanzo

por todo o vieiro,

sin muita fadiga

nin muito tormento.

Agiña se chega

ao chan que dixemos

e mais é ben ancho

todo o seu terreo.

Alí corren lebres

e cazan coellos

os homes nas festas;

dempois van vendelos. 
De alí, daquel chan

tan alto en extremo,

se ve toda a vila

cos seus arrodeos

O fragmento recorda un algo a Gonzalo de Berceo, pois diríase que o narrador fala a un público atento e sinxelo, a quen intenta distraer contándolle pequenas historias e describíndolle lugares. Son versos de seis sílabas ensartados en cuartetas, con rima asonante nos pares e impares libres. Demostra Pedro José García de Balboa (1695-1772), que tal foi o nome do simpático e sabio monxe, grande habelencia e intelixencia tamén no terreo literario. De feito, parece que as coplas alcanzaron moita popularidade.

Hai que lembrar aquí, aínda que non nos paremos na súa achega ao corpus textual literario en galego, a Diego Cernadas e Castro (1698-1777), cońecido como "O Cura de Fruíme", home, ao parecer, de envexábel erudición e autor dunha obra non escasa en castelán. Foi polemista nato, e a esta faceta súa debemos versos de gran desenfado e graza. Nel conflúen unha veta de mordente ironía, un enxeño pouco común, unha enorme humanidade e, sobre todo, un desenfreado amor por Galicia que atravesa toda a súa obra, a cal foi, en palabras de Manuel Murguía, "un grito de indignacion de Galicia contra las injusticias de que era víctima”. De aí, a simpatía con que sempre foi visto o Cura de Fruíme na súa terra.

Tampouco debemos esquecer unha íntima amiga de tan pintoresco personaxe, que tal foi María Francisca de Isla Losada (1734-1808).

Dende o punto de vista literario que vimos adoptando até aquí, quizais nos interese máis, a pesar da escasísima obra de creación que nos legou, un acendrado defensor de Galicia que foi economista e historiador e home de Estado, pero tamén fino poeta, a xulgar por un soneto de corte prerromántico, tocado do sentimentalismo da época, que nada ten que envexar a outros escritos por aquel tempo noutras linguas e moi aplaudidos no ámbito das literaturas normalizadas. Foi Xosé Cornide e Saavedra (1734-1803), galego instalado en Madrid que, dende os seus escritos profesionais, soubo denunciar o trato de colonia ("porque quieren que Galicia sea país de Indias”) que vińa sufrindo a súa terra natal por 
parte do poder central madrileño. E se traio isto a colación é debido a que, como xa vimos na proclama de 1846, este sentimento de país colonizado atravesará, deica en adiante, toda a historia de Galicia, mesmo até hoxe, e condicionará tamén boa parte da súa literatura.

Pero fixémonos agora na finura do soneto "A Filida”, exemplo único do que puido ser a literatura prerromántica en Galicia, se existise tecnicamente como tal e, en tal caso, seguise un proceso normal de canonización e institucionalización.

\section{A Filida}

¿Viche, Filida amada, o pajarińo

que arando desos aires nas campiñas,

descoidado se achanta polas liñas

que cauto cazador pon no camiño?

¿Viche que forza fai para soltarse

e levar a bicada ós seus pajaros

(parte do corazón e fillos caros),

que deixara no niño ó remontarse?

Pois viche a quen che adora pola vida, que, chantado no ichó de un imposibre, cat $a$ aquí, cat $a$ alí se acha saída

para fugir, podendo verse libre

e acurrujarse firme no teu seo, en que chocara atento o seu deseo.

Os ben trazados hendecasílabos, a delicadeza de sentimentos, o sutil fonosimbolismo en africadas e fricativas prepalatais e en vogais extremas da serie alta palatal en posición tónica co que se apoia o significado do poema (o amado é coma un paxariño que chora, que chía, imposibilitado de volver ao seu niño, é dicir, ao seo da amada) fan del unha xoia do corpus textual galego engastado no 


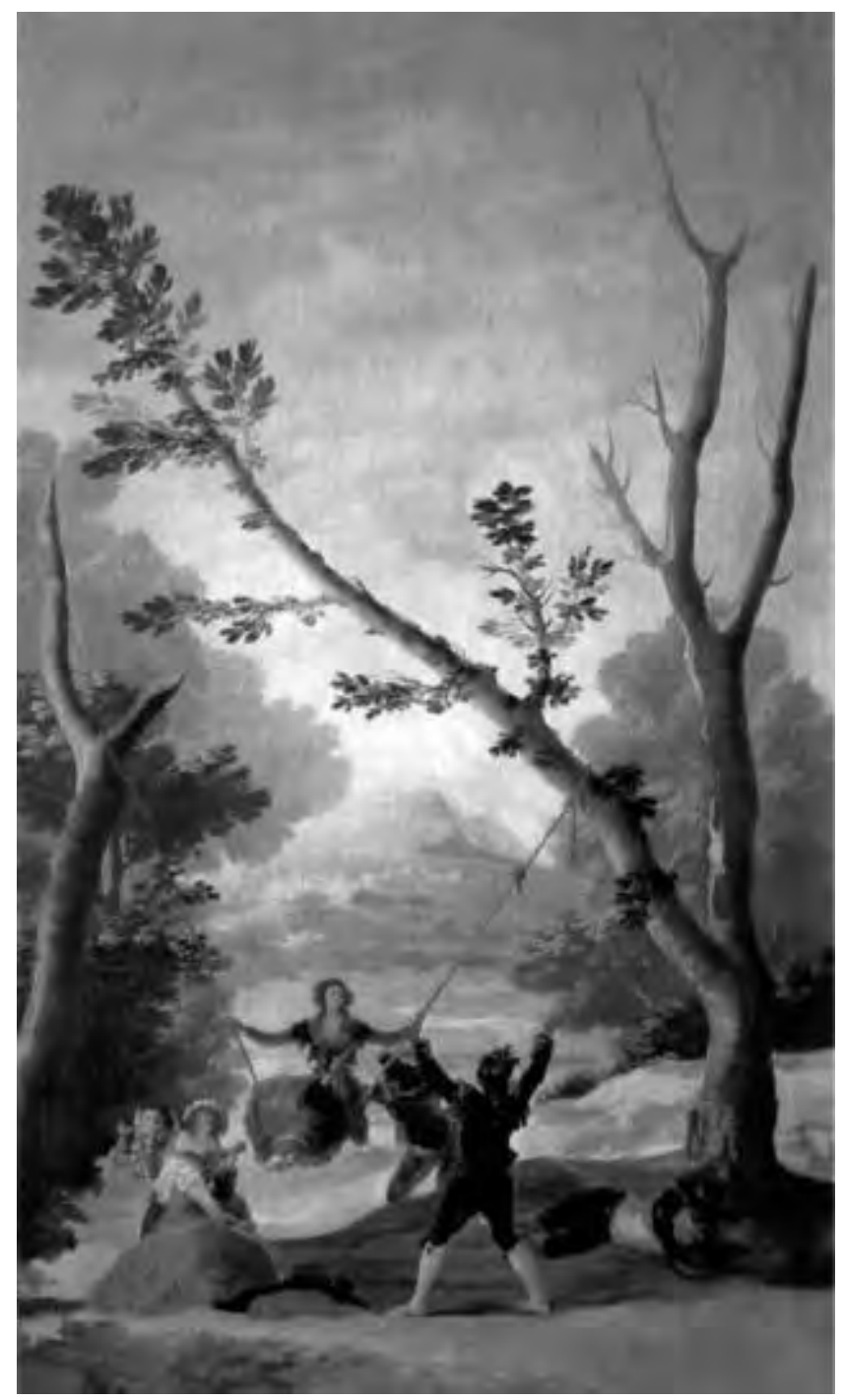

movemento europeo do prerromanticismo ou do rococó. É dicir: Cornide foi un artista que viviu o seu tempo, como quería Germaine Necker, Madame de Staël. Así mesmo, non foi alleo Cornide ao rexoubeo literario con algunhas composicións, das que xa vimos antes unha mostra e outras varias que podiamos aducir aquí, elaboradas con graciosos versos e un desenfado que abundou no século dezanove galego a base case exclusivamente de restras octosilábicas. 
Así as cousas, chegamos outra vez ao ano 1797, que é onde comeza o corpus obxecto deste simposio. Indubidabelmente, atopamos neste corpus, por unha parte, un tipo de textos versificados que, en boa medida, representan dende o punto de vista formal e dos horizontes estéticos anteriores, se non un retraso si unha continuación sen moito máis mérito que o plus engadido de estaren redactados en lingua galega, é dicir, cunha escolla repertorial descentrada e marxinal respecto do sistema canónico literario imperante, que non era outro que o sistema literario español. Isto cómpre telo en conta polo que conleva de xesto alternativo, obviando que moitos destes textos teñan unha finalidade propagandística evidente e polo tanto que estean feitos cunha función pragmática procurada mediante a que se esperaba unha difusión oral nos faladoiros populares, nos fogares, nas lareiras e nos atrios das igrexas, é dicir nos cronotopos populares tipicamente galegos, como xa adiantei antes.

Por outra parte, tamén atopamos unha relativamente abundante mostra de textos en prosa que teñen unha intencionalidade semellante aos anteriores, cos que ademais coinciden en acudir ao formato dialogado, seguramente por intuír que é un xénero moi ameno para un público maioritariamente analfabeto que gozaría cos enxebres deseños e ditos dos personaxes. A utilización da diglosia supón nestes textos un efecto verosimilista que está en función de crear a ilusión de realidade verificábel.

Este tipo de textos, como xa se dirá sobradamente nestes relatorios, non teñen apenas interese lidos dende o punto de vista do dinamismo formal e ideolóxico de renovación dos paradigmas que toda manifestación estética debe procurar, dende o momento en que non se aprezan propostas novas (agás nos casos que veremos), respecto do que xa se vińa facendo ao longo dos séculos anteriores e do que vimos algunhas mostras.

En boa medida, sempre falando dende o punto de vista sistémico-literario, os textos que conforman o libro dos Papés d'emprenta condenada teñen o valor de contribuír ao incremento do corpus textual que toda literatura necesita para se lexitimar e presentar cos seus trazos diferenciados perante o resto do mundo. Por iso, cando comecen verdadeiramente a perfilarse planificacións culturais, no sentido que lle dá á expresión a teoría de polisistemas (Even-Zohar 1999), é dicir estratexias efectivas para estabelecer un campo cultural galego diferenciado, estes textos pasarán a engrosar o patrimonio textual na lingua do país. Pero esa plani- 
ficación non comezará a dar os seus primeiros agromos até a segunda metade do século XIX, aínda que o xermolo podemos atisbalo xa na proclama da Junta del Gobierno de Galicia que xa vimos antes e no manifesto literario que redactou o grupo de Antolín Faraldo, titulado "Nuestra bandera literaria", malia ser escrito en castelán. Moito habería que dicir sobre a utilización que fai alí facía Antolín Faraldo da expresión literatura gallega, que naquel intre significaba literatura española regional escrita por gallegos, pero non está dentro dos obxectivos asignados para hoxe.

Que dúbida hai, por outra parte, de que a presenza entre os textos que nos ocupan da pecińa teatral do indomábel Antonio Benito Fandiño, A casamenteira, redactada en 1812 , pero non editada cunha tirada escasa até 1849 , ten grande interese, anque non sexa máis que anecdótico, por constituír a primeira mostra de texto dramático para representar que se coñece da época contemporánea.

Tamén é de interese para a historia da literatura galega a presenza de poetas que máis adiante protagonizarán propiamente o estabelecemento dalgúns protoalicerces, valla a expresión, para a lenta e demorada construción do sistema literario de que gozamos a día de hoxe. Efectivamente, a presenza de textos inéditos ou daqueloutros que resultan ser primixenios de Marcial Valladares, Xoán Manuel Pintos, os irmáns Camino Sigüer, Vicente Turnes, Francisco Añón e algúns outros, enriquece sobranceiramente, dende o punto de vista cuantitativo, o patrimonio textual galego, e isto non podemos obvialo.

Cousa algo distinta nese corpus xeral é a mostra que se edita nos Papés d'emprenta condenada do poeta viveirense Nicomedes Pastor Díaz Corvelle (Viveiro 1811-Madrid 1863), por máis que xa se cońecera dende hai moitos anos, sobre todo da man de Xosé María Álvarez Blázquez e a súa voluntarista editorial Monterrey, nomeadamente, en 1951, tanto para o que atinxe á Alborada, asinada en 1828, cando Nicomedes tińa 17 anos, para o xornal El Museo Artístico Literario e reproducida posteriormente en moitas antoloxías e recompilacións da poesía de Pastor Díaz, como para o que se refire á Égloga de Belmiro e Benigno, tirada dun manuscrito anónimo que atoparon Álvarez Blázquez e Luís Viñas Cortegoso, pero que non deixa lugar a dúbidas acerca da autoría de Pastor Díaz, como ben explica Ramón Mariño na introdución á edición do texto tirada directamente dese manuscrito depositado a día de hoxe na Fundación Penzol. 
Ambas as dúas composicións gozan hoxe dun estatus literario especial outorgado por retroalimentación ou feed back á vista da valorada obra de Pastor Díaz como poeta no macrosistema literario español do romanticismo, no que ocupa un lugar canónico central que ilumina, aínda que non sexa máis que en penumbra, estas dúas pezas galegas. Dous poemas que, doutro xeito, habían pasar desapercibidos e, por suposto, minorizados pola historiografía literaria española se a correspondente galega non exercese presión. A alborada é unha composición poética que podemos inscribir na tradición neoclásica. Trátase, como ben soubo ver Francisco Fernández del Riego, do primeiro balbucido lírico do século XIX galego. Nesta composición, Pastor Díaz demostra que xa na súa adolescencia coñecía perfectamente as técnicas da égloga renacentista, modelo Garcilaso, e as poesías sentimentais, modelo Meléndez Valdés.

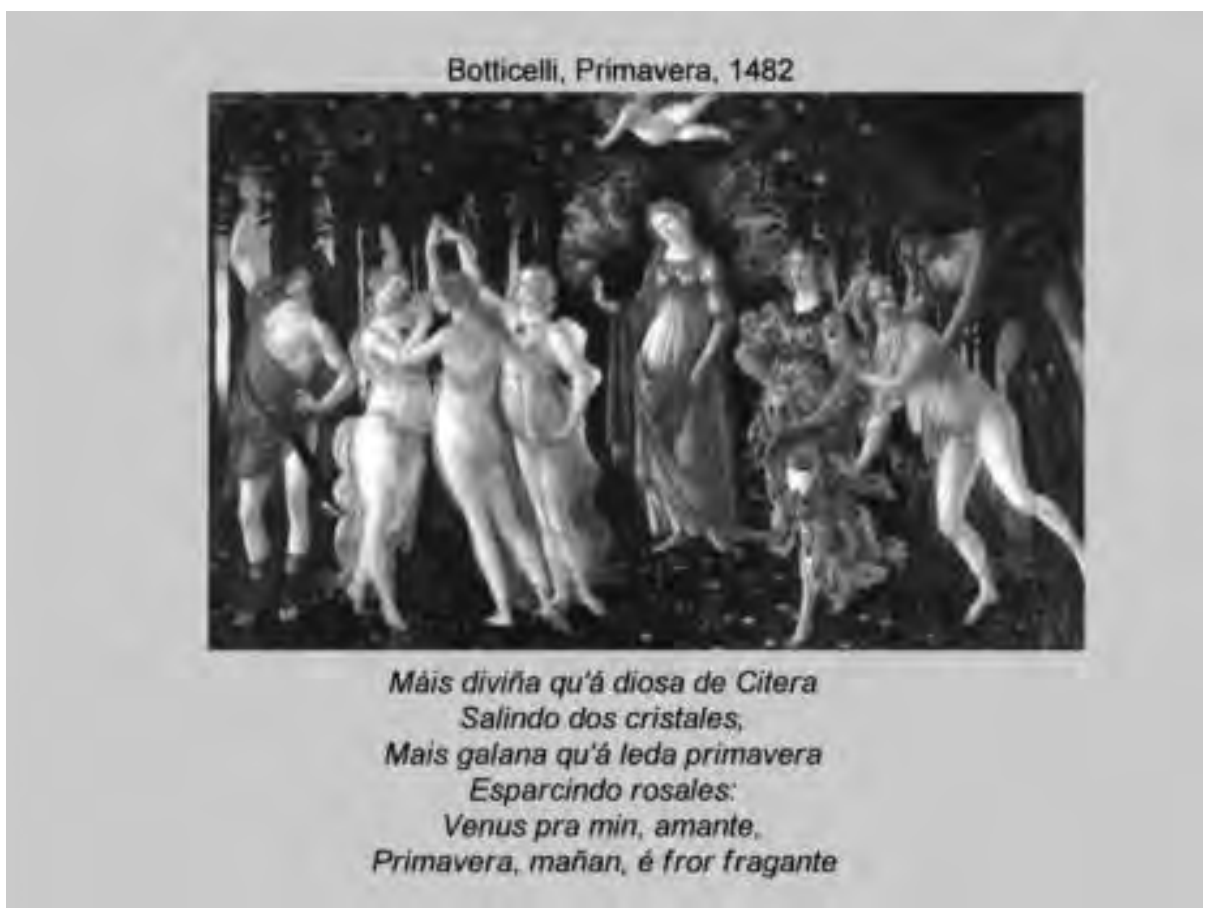

O autor empregou liras e estancias de seis versos hendecasílabos e heptasílabos para glosar un delicado tema amoroso: o amado evoluciona cos seus cantos por un locus amoenus á hora da alba, mentres agarda a que esperte a súa amada. 
Vexamos unha pequena mostra: As referencias mitolóxicas, o ambiente bucólico e a serenidade apolínea, horaciana, que respira toda a composición, coido que nos autorizan a falar dun Pastor Díaz prerromántico, se acaso xa moi próximo a deixar que o seu talante romántico eclosione, como veremos que fará axińa, pois as "penhas" e as "lúgubres cadenas" que no imaxinario lector xa van asociadas ao romanticismo, renxen bastante no medio de tanta apacibilidade:

\author{
Verásme aquí cantando, \\ Xunto estas augas craras, estas penhas, \\ Verásme aquí agardando \\ Que se rompan as lígubres cadenas \\ D'a noite que m'aparta \\ De quén nunca á alma miña se véu farta.
}

Moi precoz foi Pastor Díaz como poeta romántico, pois na recompilación da súa poesía en castelán, que apareceu en 1840 e onde esta Alborada en galego resulta unha rara avis, xa se dan mostras inequívocas de que en plena adolescencia se adiantou ao asentamento do romanticismo en España. Isto recońéceno timidamente moitos observadores da poesía española decimonónica e é evidente con tan só botar unha ollada a esa mostra de cando el contaba tan só 29 anos. Foi este un mérito do viveirense que se lle releou decote na historiografía da literatura española, na que sempre se falou de Zorrilla, Espronceda, o Duque de Rivas, Larra e uns poucos máis, pero obviando Pastor Díaz ou reducíndoo á condición de "poeta menor" ou a unha escola ou "tendencia norteña, para diferenciarla de la lírica que se producía en otras regiones españolas" (Alborg: 399), se ben dicindo coa boca pequena que "Pastor Díaz escribía poesías románticas antes de 1830 " (Navas Ruiz, 255), é dicir algúns anos antes (decisivos, poderiamos dicir) da data de 1835, cando "empiezan a publicarse en los periódicos poesías románticas". Máis atinado semella a este respecto Daniel George Samuels, tamén citado por Alborg, ao dicir que

Nicomedes Pastor Díaz, poeta romántico español, merece un estudio detallado por tres razones: dejó versos de mucho valor literario, es abuelo lírico de Bécquer, y se destaca como uno de los iniciadores de las tendencias románticas en España. También puso en 
marcha unos temas y actitudes poéticas que, en gran medida, no terminan sino hasta muy avanzado el siglo XIX (Samuels, p. 1).

É neste punto onde eu querería romper unha lanza polo noso poeta, pois esa precocidade do seu romantismo respecto da serodia aparición no panorama literario español, como decote se recońece nas historias da literatura, proxectouna Pastor Díaz de xeito inequívoco na composición titulada Égloga de Belmiro e Benigno que anunciamos antes. Mesmo hai algo máis que cómpre subliñar e que non vexo reflectido na bibliografía: Pastor Díaz parece darnos indicios de que tivo acceso a algunha tradución ao castelán, ou mesmo ao francés, da novela epistolar de Goethe Die Leiden des jungen Werther (1774) bastante antes que moitos poetas do sistema literario español. E se traio Werther a escena neste punto é porque, como ben se sabe, foi esta obra de Goethe a que máis influíu na eclosión do romantismo en Europa, até o punto de inducir ao suicidio a moitas das persoas que leron esta súa novela epistolar.

Tamén é sabido, por outra parte, que a lectura desta novela pasou por atrancos inquisitoriais de tradución e difusión en España, como mínimo até a abolición do Tribunal do Santo Oficio en tempos de Sabela II, dende 1834. De feito, a tradución directa, digamos clásica, do alemán ao español, que se cita máis a miúdo é a que fixo José Mor de Fuentes en 1835, baixo o título de Las cuitas de Werther. Saíra en Barcelona e coñeceu reedicións sucesivas en Valencia e noutros lugares, á parte doutras traducións que foron aparecendo no século a cargo de especialistas varios.

Pero a primeira tradución do Werther ao español, anque dende o francés, data de 1819. Houbo antes algúns intentos de esquivar a censura, por exemplo en 1803, cando un impresor chamado José Baldeau pensaba enganar o censor presentando a novela baixo un título edulcorado: Cartas morales sobre las pasiones, pero non conseguiu o permiso, e na acta correspondente afírmase que non só lle parece mal ao censor que se trate dunha novela, senón que remate en suicidio e para colmo se atreva a facer citas da Biblia, o cal estaba expresamente prohibido pola Inquisición. A citada tradución de 1819 saíra en Valencia e mais en Barcelona, cidades nas que apareceu outra vez en 1920 e 1921, respectivamente, e mesmo foi reimpresa en 1825 en París. Pastor Díaz puido coñecer en plena adolescencia algunha tradución ou mesmo algún orixinal en francés que 
chegase por un casual ás súas mans antes de compoñer a Égloga de Belmiro e Benigno, na que dous pastores íntimos amigos choran as súas coitas de amor á beira do río Landrove:

$$
\begin{aligned}
& \text { Nas ribeiras amenas } \\
& \text { do apacible Landrove. }
\end{aligned}
$$

Dende o punto de vista formal a composición contén máis imperfeccións cá $\mathrm{Al}$ borada e, unha vez máis, o autor tentou aclimatar a égloga clásica ao idioma galego, conseguindo, sen dúbida, un froito apreciábel, aínda que cargado de tópicos e de inxenuidade nas rimas (logradas en moitas ocasións a base de morfemas gramaticais), ademais dalgunhas impericias métricas nas estancias de catorce versos, hendecasílabos e heptasílabos, de que se serviu para a composición, de fábrica plenamente romántica dende o punto de vista ideolóxico e do imaxinario a que remite, como pode ser a desacougante paisaxe, moi lonxe do tranquilo locus amoenus da égloga clásica que lle servira de modelo para a Alborada. Como proba están os "nubarróns", o "manto mouro" da noite sen estrelas e a visión do namorado desesperado subido a "unhas altas penas" co abismal mar no fondo batendo "con feroz ruxido".

Xá por detras dos montes se escondia

O rubo pai da luz en carro de ouro

De nubarros ó ceo se cubria

Tendia á noite ó lexos manto mouro

Enterraba ó Tesouro

$\mathrm{O}$ avaro gardador medio as escuras

Cando sentado en unhas altas penas

Que ó mar batia con feroz ruxido

Ardendo en lume vivo as suas venas

Centellandolle os ollos encendidos

Xamais adormecidos,

Belmiro labrador se lamentaba

$\mathrm{E}$ os seus gritos alzaba

Os ceos dos seus males causadores 


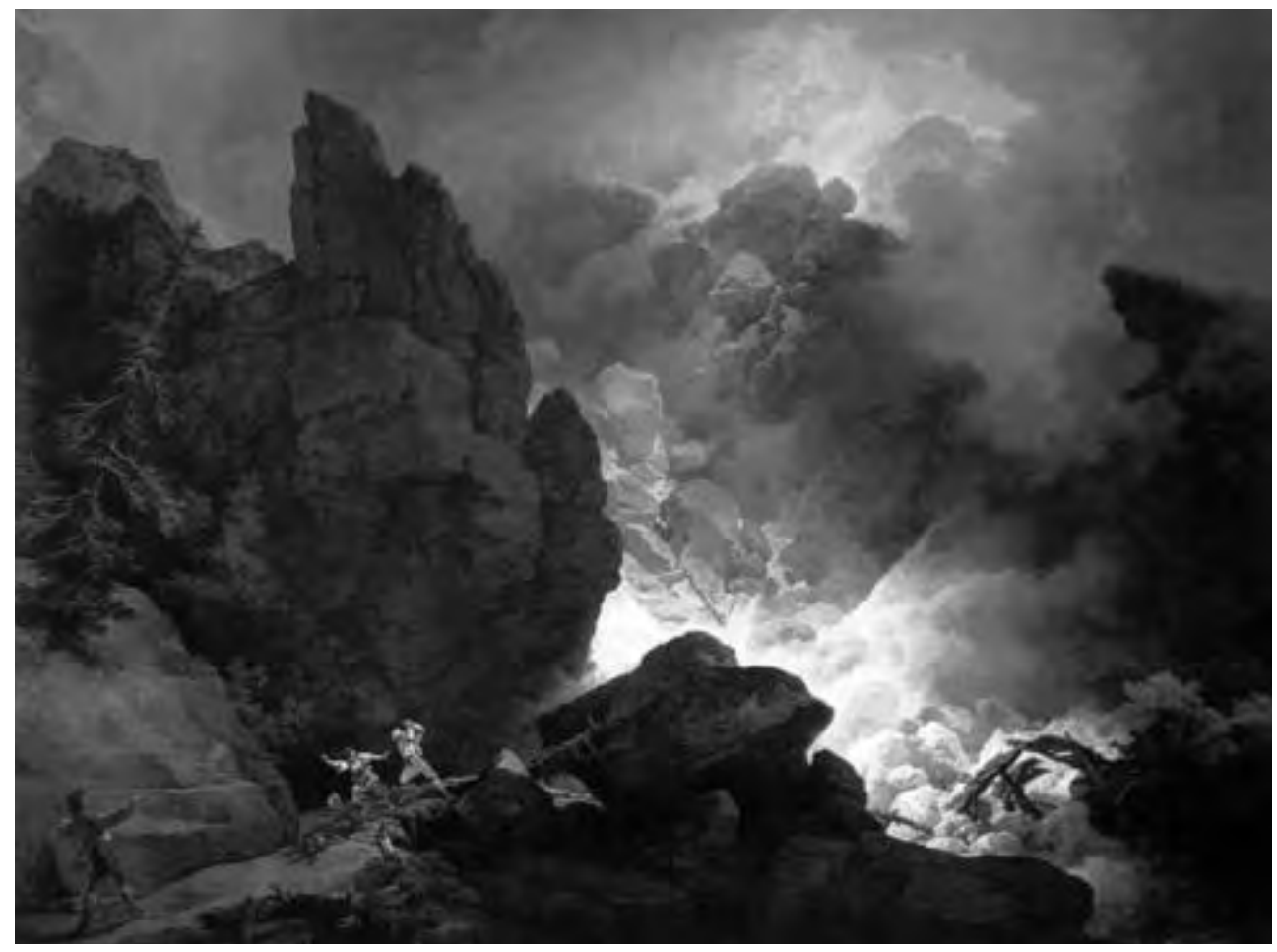

William Turner

Ese mar embravecido que evoca a iconografía romántica máis inequívoca, como pode ser a dos pintores contemporáneos seus Caspar David Friedrich ou William Turner. A mesma que se atopa no arrinque e en moitas pasaxes do Werther:

El sol iba a esconderse detrás de las montañas cuando llegamos a la puerta de entrada. El aire era pesado y difícil era respirar, se veían arremolinarse en el horizonte ingentes y numerosos nubarrones de un color oscuro.

Nesta composición reúne Pastor Díaz moitos dos topoi característicos do Romantismo europeo, como pode ser a atracción do abismo, a desesperación que leva á loucura ou a tentación do suicidio, que no Werther se consuma, como ben se sabe; o pesimismo melancólico, a crenza na imposibilidade da realización individual, a 
sublimación da amizade, a patética figura do triste, que tan maxistralmente glosará moitos anos despois a grande amiga de Pastor Díaz, Rosalía de Castro, etc.

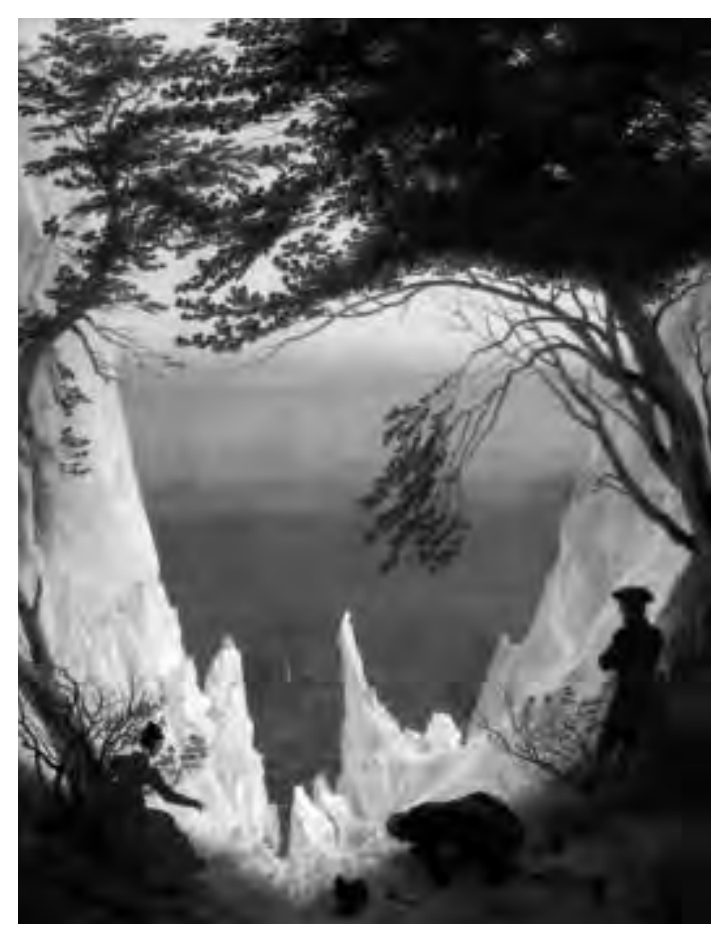

Cadro de 1818-1819: Xente ao bordo do abismo. Caspar David Friedich (1774-1849)

Pero Werther suicídase porque non atopa ningún elemento con que se agarrar á vida sen o amor imposíbel da súa amada Carlotte, ou Lotte, casada cun amigo seu a quen non quere traizoar. Nin a amizade con Guillerme, que é o correspondente das súas cartas, nin o consolo da relixión, pois nin sequera unha instancia transcendente pode acudilo no seu desespero. Recordemos que a novela remata con estas palabras: "Uns xornaleiros levaron o cadaleito. Non o acompańou ningún crego".

Non ocorre o mesmo con Belmiro, trasunto ideolóxico de Pastor Díaz, que conta co seu amigo Benigno, que o convence para que non se tire a vida, poñéndolle a Deus por diante, como fará Rosalía co seu triste e desesperado personaxe a quen tanto atrae o abismo e as bravas ondas do mar cántabro. 


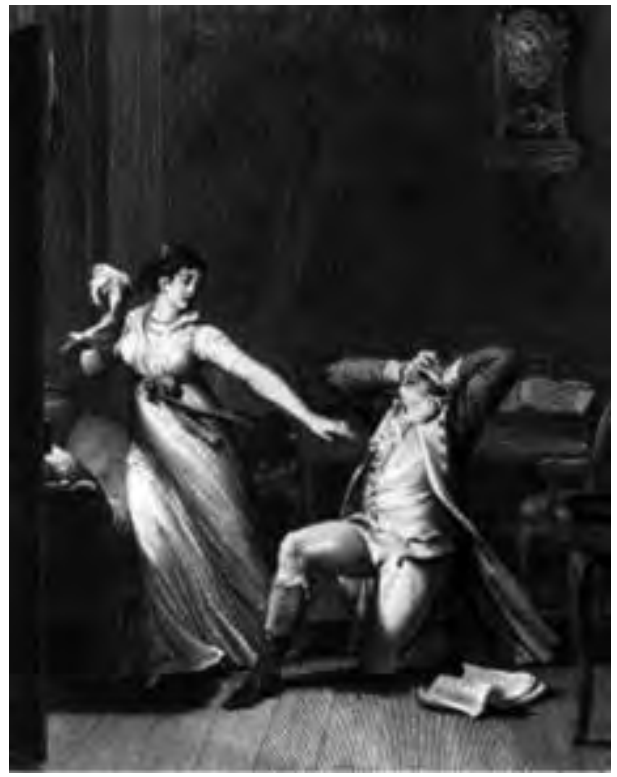

Werther con Lolotte. A piques da loucura por un amor imposíbel

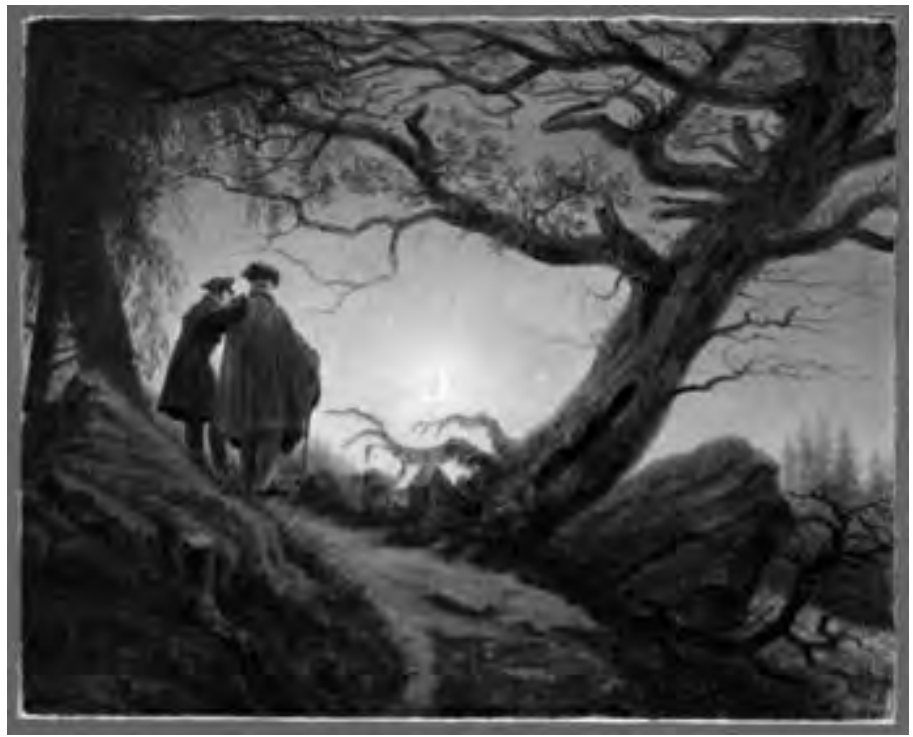

Caspar David Friedrich. Dous Amigos miran a lúa (c. 1830) 
Polo demais, é dicir, se disimulamos a decisión de Belmiro de volver canda os seus e non se tirar ao mar para acompañar á súa amada afogada, a impronta romántica da Égloga de Pastor Díaz dános autorización para dicir que tamén nesta ocasión a lingua galega non só servía para se acoller ao dinamismo que se esixe a todo sistema literario, senón que foi pioneira no macrosistema literario español á hora de pulsar os rexistros románticos, tal como fixo tamén Pastor Díaz a través da súa poesía en castelán, a lingua que lle proporcionou os loureiros que os mesmos contemporáneos seus non puideron relearlle.

Ben se decatou Otero Pedrayo da significación que no seu tempo representou Pastor Díaz en España e en Galicia ao facer del unha moi postiva valoración como poeta, político, administrador e orador:

Algús dos nosos millores inteleitoales —Villar Ponte, Vicente Risco- considérano o Románteco tipo. Xa Murguía dende o punto de vista galego escramara: Il foi o primeiro. (...) era na vida o poeta máis fondamente pesimista do século dazanove na España. Non era finxido, coma outros, seguindo a moda do día (...) a súa tristeza é tan grande e fonda que figura representare no mundo unha coarta dimensión. Era amigo de Fígaro; o mundo pra il un cemiterio como aquil que pintou Fígaro no seu derradeiro artigo. Mais PD tiña fé relixiosa e, aínda que non confesada, tiña tamén unha outra fé que non lle falta a todo bo galego. A ispirazón sorprende ô poeta na orela do mar; é unha musa (...) Pastor Díaz non agarda nada da vida, nin da razón. Ôs vint’anos sinte unha man fría no leito; esprimenta un medo; non era o tempo nin a morte, pois ista como noiva arelada pol-o poeta tén a man doce, suave, a man liberdadora. (...) Era a man fría, a razón”. PD, e con el todol-os sensitivos faltos de alegría creadora do pensamento, afundíronse confiadamente n'un radical desespero. A lúa era un frío penedo xirando traxicamente no oco dos ceos valeirado pol-a cencia. Apenas disfroitóu o poeta da mocedade: estaba ledo, mais chegou a mariposa negra: $<$ A veces creo que un sepulcro amado / lanzó bajo esta lava aterradora / el espíritu que aún adora / mi yerto corazón. >> (...) Por iste carauter seu, de pimeiro noivo da poesía, foi sin dúbida PD un xefe dos romántecos (...). Mais tampouco olla a morte com'unha redenzón: quer vivir có seu door, que figura o eixe da súa ialma, coma se lee n'unha das poesías máis fermosas <<La inmortalidad >>, escrita en 1829 en verso libre d'outo tono. Nista arela de inmortalidade, abrazado á door ¿non latexa a razón de vivir do Romantismo, e tamén o sentido oucidental, atránteco, da vida? Pastor Díaz somente atopa acougo na beiramar patrea. Foi un poeta de mar. Sentía n’ela unha 
sinxeleza d'orixes xeolóxicos, a infindade d'un elemento sempre cambiante, a novidade dos seus soños, a ceibe indifrenza purificadora.

(...) Seu ideal políteco podería tidoarse: liberdade dentro da relixión.

(...) Pastor Díaz dá unha soluzón relixiosa: Socialismo baixo o Evanxelio (...).

Pois ben, e xa para rematar estes modestos apuntes: todo isto que vimos hoxe aquí e algunhas cousas máis fíxose dende a carencia máis absoluta dos elementos necesarios para configurar o que entendemos por un sistema literario ou mesmo do que se dá en chamar unha literatura nacional. Trátase dun corpus textual abondo pequeno, o que poderiamos reunir con composicións escritas nos case cinco séculos que median entre o final do esplendor literario galego medieval e os textos que se recollen no libro Papés d'emprenta condenada. Moi pequeno, sobre todo, se o comparamos co enorme patrimonio que na altura de mediados do século XIX reuniran xa as literaturas europeas normalizadas en linguas vulgares, en xeral, e as románicas particularmente, por máis que este pequeno corpus nos ilumine por veces o camiño para comprender o que ocorreu coa expresión literaria en galego durante o que moi axustadamente se denominan séculos escuros da Historia de Galicia, non só das súas letras. 


\section{BiBLIOGRAFÍA}

Alborg, Juan Luis. 1980. Historia de la literatura española.Vol. IV. El Romanticismo. Madrid: Gredos.

Blanco Echauri, Xesús et alii. 2006. Nicomedes Pastor Díaz, unha existencia exemplar. De Ramón Vilar Ponte. Lugo: Fundación Caixa Galicia.

Cassany, Daniel. 2006. Tras las líneas. Sobre la lectura contemporánea. Barcelona: Anagrama, 2006.

Dubors, JaCQues. 1978. L'Institution de la littérature: introduction á une sociologie. París: Nathan.

Equipo Glifo. 1998-2003. Dicionario de termos literarios. En proceso de redacción: vol. I (A-D), vol. II (E-H). Santiago de Compostela: Centro Ramón Piñeiro para a Investigación en Humanidades. Dende 2006 poden consultarse tamén en lińa as entradas do I ao M : http://www.cirp.es. (Base de datos DiTerLi)

Even-Zohar, Itamar. 1999. «Planificación de la cultura y mercado». En Montserrat Iglesias Santos (ed.). 1999. Teoría de los Polisistemas, Madrid: Arco, pp. 71-96.

Fernández del Riego, Francisco. 1998. Antolín Faraldo, o Gran soñador. Vigo: Edicións Xerais de Galicia. Habermas, Jürgen, [1962]1981. Historia y crítica de la opinión pública:la transformación estructural de la vida pública [Strukturwandel der Öffentlichkeit. Untersuchungen zu einer Kategorie der bürgerlichen Gesellschaft, 1962], tradución ao castelán de Antoni Domènech e Rafael Grasa, Barcelona: Gustavo Gili.

LefeVere, André. [1992] 1997. Traducción, reescritura y la manipulación del canon literario [Translation, Rewriting and the Manipulation of Literary Fame, 1992], tradución ao castelán de Ma Carmen África Vidal e Román Álvarez. Salamanca: Varona, 1997.

Navas Ruiz, Ricardo e Díez Taboada, J.M, “Poesía romántica y posromántica”, en Francisco Rico (dir.). 1982. Historia crítica de la literatura española. Vol. 5. Iris M. Zavala (coord.) Romanticismo y realismo, pp. 254-263.

Necker, Germaine, v. Staël, Madame de.

Otero Pedrayo, Ramón. 1998. A paixón e o discurso de Otero Pedrayo: Galicia, A Coruña: Deputación provincial de A Coruña.

Samuels, Daniel George. 1943. "Pastor Díaz: romántico español ", Revista Hispánica Moderna. IX, pp. 1-16.

StaËL, MadAme DE. 1800. De la Littérature considerée dans ses rapports avec les institutions sociales. Édition critique par Paul van Tieghem. Genève: Droz, 1959.

Tarrío Varela, Anxo.1994. (1a reimp. 1998). Literatura galega. Aportacións a unha Historia crítica. Vigo: Edicións Xerais de Galicia 